\title{
Extrapulmonary Small Cell Carcinoma - a Case Series of Oropharyngeal and Esophageal Primary Sites Treated with Chemo-Radiotherapy
}

\author{
Puja Sahai ${ }^{1 *}$, Saphalta Baghmar ${ }^{2}$, Devajit Nath ${ }^{3}$, Saurabh Arora ${ }^{4}$, Suman \\ Bhasker $^{1}$, Ajay Gogia ${ }^{2}$, Kapil Sikka ${ }^{5}$, Rakesh Kumar ${ }^{4}$, Subhash Chander ${ }^{1}$
}

\begin{abstract}
Background: The optimal sequence and extent of multimodality therapy remains to be defined for extrapulmonary small cell carcinoma because of its rarity. The purpose of our study was to assess the response to neoadjuvant chemotherapy followed by chemoradiation/radiation in patients with extrapulmonary small cell carcinoma. Materials and Methods: Four consecutively diagnosed patients were included in this study. The primary tumor site was oropharynx in three patients and esophagus in one. The patients with the limited disease were treated with chemotherapy followed by concurrent chemoradiation $(n=2)$ or radiotherapy $(n=1)$. The patient with the extensive disease with the primary site in vallecula was treated with chemotherapy and palliative radiotherapy to the metastatic site. Results: The median follow-up was 22.5 months (range, 8-24 months). Three patients with the limited disease (base of tongue, $n=2$; esophagus, $n=1$ ) were in complete remission. The patient with the extensive disease died of loco-regional tumor progression at 8 months from the time of diagnosis. Conclusions: The combination of chemotherapy and radiotherapy is the preferred therapeutic approach for patients with extrapulmonary small cell carcinoma. Induction chemotherapy followed by concurrent chemoradiation or radiation provides a good loco-regional control in patients with limited disease.
\end{abstract}

Keywords: small cell carcinoma - neuroendocrine carcinoma - extrapulmonary - head and neck neoplasms - esophagus

Asian Pac J Cancer Prev, 16 (16), 7025-7029

\section{Introduction}

Extrapulmonary sites constitute $5.8 \%$ of all small cell carcinoma (SCC) cases (Wong et al., 2009). A better 3-year survival has been reported for patients with extrapulmonary small cell carcinoma (EPSCC) as compared to small cell lung cancer (19\% vs 5\%) (Wong et al., 2009). Though there have been recent institutional experiences with EPSCC, clear guidelines regarding the optimal sequencing and extent of the multimodality therapy remains to be defined. Most of the cases of EPSCC arise in the gastrointestinal tract, with esophagus being the most common site (Wong et al., 2009). Head and neck SCC constitutes 11-21\% of all extrapulmonary sites (Lin et al., 2007; Ochsenreither et al., 2009; Wong et al., 2009; Brennan et al., 2010). The majority of cases of SCC in the head and neck region involve trachea, thyroid, and larynx followed by oral cavity, sinonasal, and pharynx (Wong et al., 2009). We prospectively assessed the treatment outcome with induction chemotherapy followed by chemoradiation/radiation in three cases of oropharyngeal and one of esophageal SCC.

\section{Materials and Methods}

Four patients were diagnosed with EPSCC in our multidisciplinary clinic from September to October 2013 and followed up till August 2015. The patient and disease-related characteristics are summarized in Table 1. Radiologic images of the four cases are illustrated in Figure 1. Two patients with limited disease (LD) of the base of tongue were treated with 2-3 cycles of neoadjuvant chemotherapy (NACT) followed by concurrent chemoradiation (CCRT). A 3-weekly schedule of cisplatin/etoposide for neoadjuvant and weekly cisplatin was used for concurrent chemotherapy. The patient with the esophageal primary tumor (LD) was treated with 6 cycles of NACT in view of extensive loco-regional disease. Since, she achieved complete metabolic remission after NACT, definitive radiation alone was delivered. The patient with extensive disease (ED) with the primary site in vallecula was treated with chemotherapy and palliative radiotherapy to the vertebral metastatic site. The patients were followed at monthly intervals for 6 months and 2 monthly thereafter. The disease-related outcome was assessed.

${ }^{1}$ Department of Radiation Oncology, ${ }^{2}$ Department of Medical Oncology, ${ }^{3}$ Department of Pathology, ${ }^{4}$ Department of Nuclear Medicine, ${ }^{5}$ Department of Otorhinolaryngology - Head and Neck Surgery, All India Institute of Medical Sciences, New Delhi, India *For correspondence: drpujasahai@gmail.com 
Puja Sahai et al

Table 1. Patient and Disease-related Characteristics of Four Cases of Extrapulmonary Small Cell Carcinoma

\begin{tabular}{|c|c|c|c|c|}
\hline $\begin{array}{l}\text { Character- } \\
\text { istic }\end{array}$ & Case 1 & Case 2 & Case 3 & Case 4 \\
\hline Age (years) & 61 & 55 & 62 & 56 \\
\hline Gender & Male & Female & Male & Female \\
\hline $\begin{array}{l}\text { Duration of } \\
\text { symptoms } \\
\text { (months) }\end{array}$ & 2 & 3 & 4 & 5 \\
\hline Symptoms & $\begin{array}{l}\text { Dysphagia, odynopha- } \\
\text { gia }\end{array}$ & $\begin{array}{l}\text { Foreign-body } \\
\text { sensation throat }\end{array}$ & $\begin{array}{l}\text { Dysphagia, odynophagia, } \\
\text { bleeding episodes from oral } \\
\text { cavity }\end{array}$ & $\begin{array}{l}\text { Dysphagia, retrosternal pain, ano- } \\
\text { rexia, weight loss }\end{array}$ \\
\hline Smoking & Yes & Yes & Yes & Yes \\
\hline $\begin{array}{l}\text { Perfor- } \\
\text { mance status } \\
(\mathrm{ECOG})\end{array}$ & 1 & 1 & 1 & 2 \\
\hline $\begin{array}{l}\text { Clinical ex- } \\
\text { amination }\end{array}$ & \begin{tabular}{|l|} 
Bilateral level II lymph \\
nodes; proliferative \\
growth base of tongue \\
extending to valleculae, \\
epiglottis; bronchos- \\
copy normal \\
\end{tabular} & $\begin{array}{l}\text { Irregularity on } \\
\text { right tonsillo- } \\
\text { lingual sulcus, base } \\
\text { of tongue }\end{array}$ & $\begin{array}{l}\text { Bilateral level II and right } \\
\text { level IV lymph nodes; ulcero- } \\
\text { proliferative growth bilateral } \\
\text { valleculae extending to lin- } \\
\text { gual surface of epiglottis, size } \\
5 \times 4 \mathrm{~cm}\end{array}$ & $\begin{array}{l}\text { No lymphadenopathy; upper gas- } \\
\text { trointestinal endoscopy: ulcerated } \\
\text { growth at } 20 \mathrm{~cm} \text { extending till } 30 \\
\mathrm{~cm} \text {; bronchoscopy normal }\end{array}$ \\
\hline $\begin{array}{l}\text { Blood inves- } \\
\text { tigations }\end{array}$ & Within normal limits & $\begin{array}{l}\text { Serum alkaline } \\
\text { phosphatase } 369 \\
\text { IU (normal } 80- \\
240) ; \\
\text { rest within normal } \\
\text { limits }\end{array}$ & Within normal limits & Within normal limits \\
\hline $\begin{array}{l}\text { Baseline } \\
\text { serum } \\
\text { albumin } \\
(\mathrm{gm} / \mathrm{dl})\end{array}$ & 4.5 & 5.1 & 3.4 & 4.3 \\
\hline $\begin{array}{l}\text { Radiological } \\
\text { findings }\end{array}$ & $\begin{array}{l}\text { CECT neck, chest, } \\
\text { abdomen: mass le- } \\
\text { sion base of tongue, } \\
4 \times 2.6 \times 2.4 \mathrm{~cm} \text {, extend- } \\
\text { ing to epiglottis, intrin- } \\
\text { sic muscles of tongue; } \\
\text { multiple enlarged } \\
\text { lymph nodes in bilat- } \\
\text { eral level II and right } \\
\text { level III, largest in right } \\
\text { level II (2.8x1.6 cm) }\end{array}$ & $\begin{array}{l}\text { 18F-FDG PET-CT: } \\
\text { soft tissue thick- } \\
\text { ening in base of } \\
\text { tongue with in- } \\
\text { creased uptake }\end{array}$ & $\begin{array}{l}\text { 18F-FDG PET-CT: soft tissue } \\
\text { density mass bilateral vallecu- } \\
\text { lae, extending to epiglottis; } \\
\text { multiple enlarged bilateral } \\
\text { level II, right level III, and bi- } \\
\text { lateral supraclavicular lymph } \\
\text { nodes 68Ga-DOTANOC } \\
\text { PET-CT: mass in valleculae } \\
\text { (SUVmax 7.05) and mul- } \\
\text { tiple cervical lymph nodes } \\
\text { (SUVmax 4.47); focal area of } \\
\text { increased uptake in body of } \\
\text { D6 vertebra }\end{array}$ & $\begin{array}{l}\text { CECT neck, chest, abdomen: cir- } \\
\text { cumferential thickening esophageal } \\
\text { wall from } 2 \mathrm{~cm} \text { above carina to } 2 \mathrm{~cm} \\
\text { below inferior pulmonary veins; loss } \\
\text { of fat planes between mass and left } \\
\text { atrium, inferior pulmonary veins, } \\
\text { and bronchi; infiltration of medi- } \\
\text { astinum with >90 and < } 180 \text { degree } \\
\text { contact with descending aorta; mul- } \\
\text { tiple enlarged aorto-pulmonary and } \\
\text { pretracheal nodes (SAD } 1.2 \mathrm{~cm} \text { ) }\end{array}$ \\
\hline $\begin{array}{l}\text { Histopatho- } \\
\text { logical find- } \\
\text { ings }\end{array}$ & $\begin{array}{l}\text { Small cell carcinoma; } \\
\text { immunopositivity for } \\
\text { CK (dot positivity), } \\
\text { synaptophysin, chro- } \\
\text { mogranin, CD56, and } \\
\text { TTF1; immunonegativ- } \\
\text { ity for MIC2 }\end{array}$ & \begin{tabular}{l|} 
Small cell car- \\
cinoma; immu- \\
nopositivity for \\
pancytokeratin and \\
synaptophysin; im- \\
munonegativity for \\
leucocyte common \\
antigen \\
\end{tabular} & $\begin{array}{l}\text { Small cell carcinoma; immu- } \\
\text { nopositivity for cytokeratin, } \\
\text { CD56, TTF-1, synaptophysin } \\
\text { with focal positivity for chro- } \\
\text { mogranin. }\end{array}$ & $\begin{array}{l}\text { Small cell carcinoma; diffuse immu- } \\
\text { nopositivity for synaptophysin while } \\
\text { immunonegativity for chromogra- } \\
\text { nin; MIB-1 labelling index was more } \\
\text { than } 85 \%\end{array}$ \\
\hline Primary site & Base of tongue & Base of tongue & Vallecula & $\begin{array}{l}\text { Esophagus (upper and middle tho- } \\
\text { racic) }\end{array}$ \\
\hline $\begin{array}{l}\text { Stage [lim- } \\
\text { ited/ } \\
\text { extensive } \\
\text { disease (LD/ } \\
\text { ED)] }\end{array}$ & $\mathrm{LD}$ & LD & ED & $\mathrm{LD}$ \\
\hline $\begin{array}{l}\text { TNM stage } \\
(\text { AJCC 2010) }\end{array}$ & $\begin{array}{l}\text { IVA } \\
\text { T4aN2cM0 }\end{array}$ & $\begin{array}{l}\text { I } \\
\text { T1N0M0 }\end{array}$ & $\begin{array}{l}\text { IVC } \\
\text { T3N2cM1 }\end{array}$ & $\begin{array}{l}\text { IIIC } \\
\text { T4bN2M0 }\end{array}$ \\
\hline
\end{tabular}

7026 Asian Pacific Journal of Cancer Prevention, Vol 16, 2015 

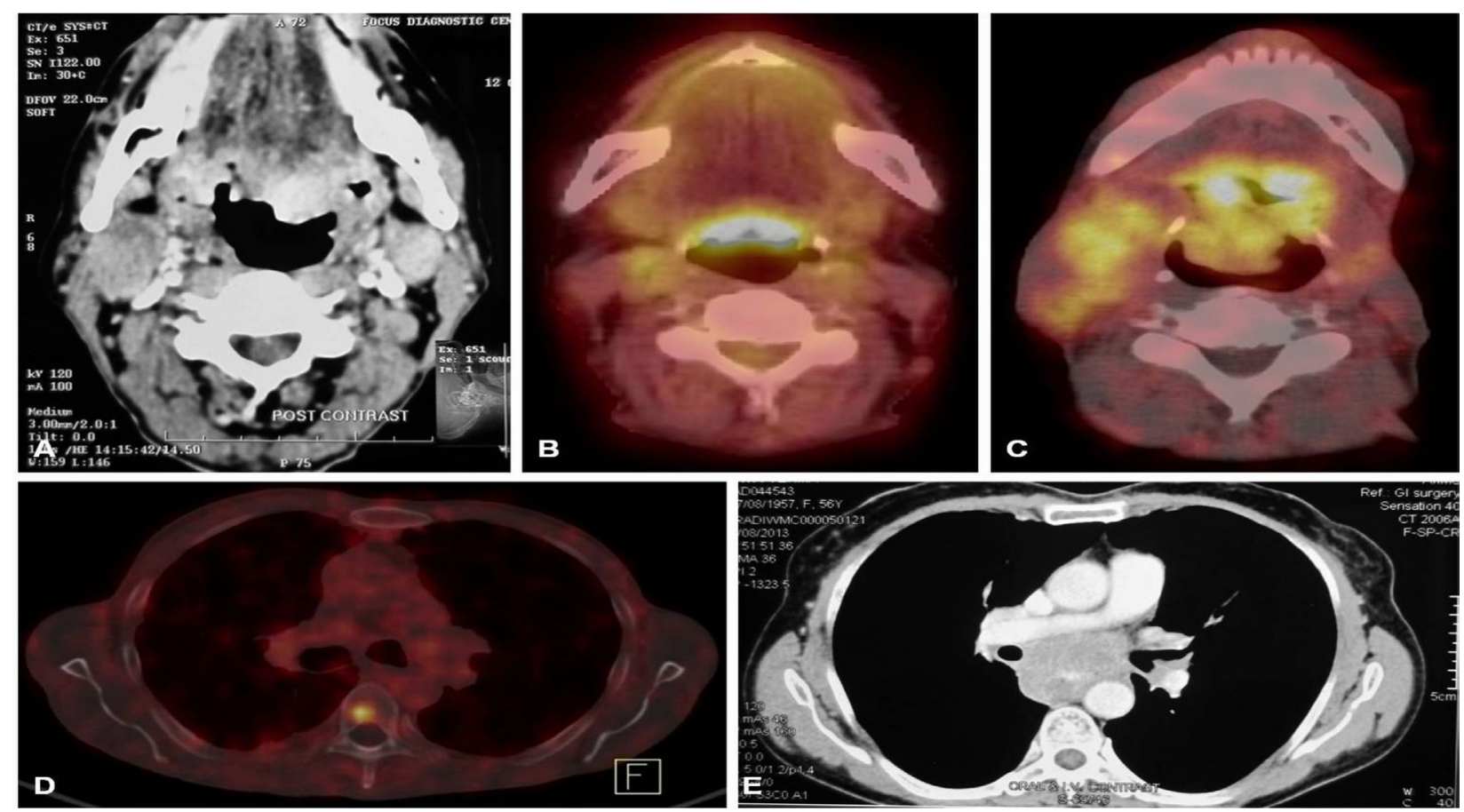

Figure 1. Axial Images of (A) CECT neck shows enhancing mass lesion involving base of tongue with bilateral cervical lymph nodes [case 1]; (B) fused 18F-FDG PET-CT shows soft-tissue thickening at base of tongue with uptake (SUVmax 6.74) [case 2]; (C) fused 18F-FDG PET-CT shows soft tissue mass involving bilateral valleculae with uptake (SUVmax 8.93), enlarged right cervical lymph nodes with uptake (SUVmax 10) [case 3]; (D) fused 68Ga-DOTANOC PET-CT (bone window) shows a small lytic lesion involving body of D6 vertebra with uptake (SUVmax 6.03) [case 3]; (E) CECT chest shows enhancing circumferential thickening of esophageal wall [case 4]

Table 2. Treatment Details and Outcome of Four Cases of Extrapulmonary Small Cell Carcinoma

\begin{tabular}{|c|c|c|c|c|}
\hline Characteristic & Case 1 & Case 2 & Case 3 & Case 4 \\
\hline $\begin{array}{l}\text { Neoadjuvant chemo- } \\
\text { therapy (NACT) }\end{array}$ & $\begin{array}{l}2 \text { cycles cisplatin } 25 \\
\mathrm{mg} / \mathrm{m} 2 \text { and etopo- } \\
\text { side100 } \mathrm{mg} / \mathrm{m} 2 \mathrm{IV} \\
\mathrm{D} 1-\mathrm{D} 3, \mathrm{q} 3 \text { weeks }\end{array}$ & $\begin{array}{l}3 \text { cycles cisplatin/ } \\
\text { etoposide }\end{array}$ & $\begin{array}{l}4 \text { cycles cisplatin/ } \\
\text { etoposide }\end{array}$ & $\begin{array}{l}6 \text { cycles cisplatin/ } \\
\text { etoposide }\end{array}$ \\
\hline Response after NACT & PR (clinically) & CR (clinically) & - & 18F-FDG PET-CT: CR \\
\hline Radiotherapy & $\begin{array}{l}70 \text { Gy/35 fractions/ } 7 \\
\text { weeks, primary tumor } \\
\text { plus bilateral neck, } \\
\text { Cobalt- } 60\end{array}$ & $\begin{array}{l}70 \mathrm{~Gy} / 35 \text { fractions } / 7 \\
\text { weeks, primary tumor } \\
\text { plus bilateral neck, } \\
\text { Cobalt- } 60\end{array}$ & $\begin{array}{l}8 \text { Gy/1fraction D5-D7 } \\
\text { Cobalt- } 60\end{array}$ & $\begin{array}{l}50.4 \mathrm{~Gy} / 28 \text { frac- } \\
\text { tions/5.5 weeks, } \\
\text { primary tumor plus } \\
\text { regional nodal regions, } \\
\text { 3-DCRT, 6MV X-rays }\end{array}$ \\
\hline $\begin{array}{l}\text { Concurrent chemo- } \\
\text { therapy }\end{array}$ & $\begin{array}{l}6 \text { cycles weekly cispl- } \\
\text { atin } 40 \mathrm{mg} / \mathrm{m} 2 \mathrm{IV}\end{array}$ & $\begin{array}{l}5 \text { cycles weekly cispl- } \\
\text { atin }\end{array}$ & - & No \\
\hline $\begin{array}{l}\text { Acute radiation mor- } \\
\text { bidity (RTOG) }\end{array}$ & $\begin{array}{l}\text { Grade } 2 \text { dermatitis, } \\
\text { Grade } 2 \text { mucositis, } \\
\text { Grade } 2 \text { pharyngitis, } \\
\text { Grade } 2 \text { salivary gland }\end{array}$ & $\begin{array}{l}\text { Grade } 1 \text { dermatitis, } \\
\text { Grade } 2 \text { mucositis, } \\
\text { Grade } 2 \text { pharyngitis, } \\
\text { Grade } 2 \text { salivary gland }\end{array}$ & - & $\begin{array}{l}\text { Grade } 1 \text { dermatitis, } \\
\text { Grade } 1 \text { esophagitis }\end{array}$ \\
\hline Response & $\begin{array}{l}\text { 18F-FDG PET-CT (at } 4 \\
\text { months): CR }\end{array}$ & $\begin{array}{l}\text { 18F-FDG PET-CT (at } 5 \\
\text { months): CR }\end{array}$ & $\begin{array}{l}\text { 68Ga-DOTANOC } \\
\text { PET-CT (after } 3 \\
\text { cycles): SD at primary } \\
\text { site and cervical lymph } \\
\text { nodes; sclerotic lesion } \\
\text { with no tracer uptake } \\
\text { in D6 }\end{array}$ & $\begin{array}{l}\text { CECT chest, abdomen, } \\
\text { pelvis (at } 3 \text { months): } \\
\text { CR }\end{array}$ \\
\hline Status at last FU & Alive with NED & Alive with NED & Died of disease & Alive with NED \\
\hline $\begin{array}{l}\text { FU after treatment } \\
\text { completion (months) }\end{array}$ & 18 & 16 & - & 15 \\
\hline $\begin{array}{l}\text { FU from date of diag- } \\
\text { nosis (months) }\end{array}$ & 22 & 23 & 8 & 24 \\
\hline
\end{tabular}

$\mathrm{PR}=$ partial response $\mathrm{CR}=$ complete response; $\mathrm{SD}=$ stable disease $; \mathrm{FU}=$ follow-up $\mathrm{NED}=$ no evidence of disease 


\section{Results}

The treatment details and the outcome are listed in Table 2. The median follow-up was 22.5 months (range, 8-24 months) from the date of diagnosis. Two patients with the primary site of base of tongue (LD) were in complete remission. The patient with esophageal primary tumor (LD) was also in complete remission. The patient with the primary site of vallecula (ED) fared poorly with the standard regimen of chemotherapy and died of locoregional tumor progression.

\section{Discussion}

With advances in the diagnostic pathological and imaging modalities, SCC is being reported more frequently in the extrapulmonary sites. The role of 18Fluorine fluorodeoxyglucose positron emission tomography (18F-FDG PET) in EPSCC has been reported (Gregory et al., 2010).A positive predictive value of $100 \%$ for staging and $82 \%$ for restaging was observed. The 18F-FDG PET scan appropriately influenced management in 8 of the 43 imaging episodes (19\%). The intent of treatment was changed from radical to palliative in five cases, and the radiotherapy volume was altered in three cases. With respect to the present series, baseline 18F-FDG PET-computed tomography (CT) was performed in two patients with the oropharyngeal primary tumor. We did 68Ga-DOTANOC PET-CT also for one patient in which a solitary skeletal metastasis was detected [Figure 1D]. However, the same metastatic site was not seen on the 18F-FDG PET-CT. On the basis of 68Ga-DOTANOC PETCT findings, the disease was assigned as extensive stage (case 3). Post-therapy 18F-FDG PET-CT demonstrated complete resolution of the disease in three patients.

In case of $\mathrm{LD}$, the therapeutic approach used in the retrospective series of EPSCC is quite varied; surgery, chemotherapy, and radiotherapy have all been used, either alone or as part of combined modality scheme (Haider et al., 2006; Lee et al., 2007; Brennan et al., 2010; Naidoo et al., 2013). The institutional reports denote that a uniform treatment protocol is not being practiced, and various regimes and dosages of chemotherapy and radiotherapy are being used. Combined modality treatment has been seen as a favorable prognostic factor for survival (Lin et al., 2007; Ochsenreither et al., 2009). Radiochemotherapy yielded the best 5-year disease-specific survival as compared to other modalities (31\% vs $13 \%$ ) for small cell carcinoma in a metaanalysis of laryngeal neuroendocrine tumors (Laan et al., 2015). Surgical resection was not associated with an improved outcome in a retrospective review of 120 patients with EPSCC seen over a span of 22 years (Brennan et al., 2010). The treatment for patients with ED of EPSCC has mainly consisted of chemotherapy.

A retrospective review (Barker et al., 2003) of nonsinonasal neuroendocrine carcinoma of the head and neck region, which included 19 cases of SCC showed improved survival with the addition of chemotherapy compared with local therapy alone. In patients treated with chemotherapy, the majority of patients received two to four cycles of induction regimen with platinum/etoposide followed by definitive radiotherapy or chemoradiation. A median dose of 66 Gy (range, 44-72 Gy) in conventional fractionation was employed for definitive radiotherapy. A minimum radiotherapy dose of $50 \mathrm{~Gy}$ in conventional fractionation has been suggested for the treatment of EPSCC (Brennan et al., 2010). Radiotherapy dose may be selected depending on the primary site of tumor involvement. In the present series, a dose of $70 \mathrm{~Gy}$ and 50.4 Gy in conventional fractionation was used for the oropharyngeal and esophageal site, respectively.

A median 1-year recurrence-free survival of $64 \%(95 \%$ CI: $38-84 \%$ ) was reported for the head and neck primary lesions in an institutional review on EPSCC (Brennan et al., 2010). Distant metastases (lung/bone/liver) have been reported in patients with head and neck SCC during follow-up after chemo-radiotherapy (Lin et al., 2007; Segawa et al., 2011; Han et al., 2012; Nakahara et al., 2012). The median time to progression for patients with LD-EPSCC has been reported at 21 months $(95 \% \mathrm{CI}$ : 0-46) while 5 months (95\% CI: 1-8) for ED (Ochsenreither et al., 2009). The median overall survival (OS) of 34 months (range, 0 2-276 months) for LD- compared with 2 months (range, 0.1-108 months) for ED-EPSCC has been described (Haider et al., 2006). The following variables correlated significantly with mortality: abnormal white blood cell count, ECOG performance status $>2$, and ED stage (Haider et al., 2006).

Stage of the tumor has been seen as a significant prognostic factor for survival in patients with EPSCC (Haider et al., 2006; Lee et al., 2007; Lin et al., 2007). The patient with ED stage in the present report had a dismal survival of 8 months. A better OS and recurrence-free survival rates have been reported for the gynecologic and head and neck primary SCC as compared to genitourinary and gastrointestinal sites (Lin et al., 2007; Brennan et al., 2010). The median follow-up for the patients with head and neck primary lesions $(n=3)$ concerning the present report was 22 months (range, 8-23 months). Two patients with the head and neck primary tumor (LD) treated with NACT followed by CCRT were recurrence-free at 1.5 years.

A study (Gollard et al., 2010) described two cases of SCC of the distal esophagus. One patient was treated with NACT followed by radiation and the other one with CCRT. The two patients died of the metastatic disease in lungs and bones, respectively. With respect to the present report, the patient with upper and middle thoracic esophageal SCC was treated with NACT followed by definitive radiotherapy. The patient remained in complete remission at a follow-up of 24 months.

A low incidence of brain metastases (4.1-13\%) has been reported in EPSCC, with the majority of cases presenting in patients with ED (Kim et al., 2004; Brennan et al., 2010; Früh et al., 2011; Naidoo et al., 2013). However, a recent article recommends prophylactic cranial irradiation (PCI) in patients with head and neck and prostate primary sites on an individual basis (Yazici et al., 2014). We did not administer PCI to the patients studied in the present report.

The combination of chemotherapy and radiotherapy is the preferred therapeutic approach for patients with 
EPSCC. Induction chemotherapy followed by concurrent chemoradiation or radiation provides a good loco-regional control in patients with LD.

\section{References}

Barker JL Jr, Glisson BS, Garden AS, et al (2003). Management of nonsinonasal neuroendocrine carcinomas of the head and neck. Cancer, 98, 2322-8.

Brennan SM, Gregory DL, Stillie A, et al (2010). Should extrapulmonary small cell cancer be managed like small cell lung cancer? Cancer, 116, 888-95.

Früh M, Kacsir B, Ess S, et al (2011). Extrapulmonary small cell carcinoma: An indication for prophylactic cranial irradiation? A single center experience. Strahlenther Onkol, 187, 561-7.

Gollard R, Ellis C, VanderHarten C (2010). Small cell/ neuroendocrine tumors of the esophagus: presentation of two cases and review of the literature. Tumori, 96, 780-3.

Gregory DL, Brennan SM, Stillie A, et al (2010). Impact of $18 \mathrm{~F}$-fluorodeoxyglucose positron emission tomography in the staging and treatment response assessment of extrapulmonary small-cell cancer. J Med Imaging Radiat Oncol, 54, 100-7.

Haider K, Shahid RK, Finch D, et al (2006). Extrapulmonary small cell cancer: a Canadian province's experience. Cancer, 107, 2262-9.

Han G, Wang Z, Guo X, et al (2012). Extrapulmonary small cell neuroendocrine carcinoma of the paranasal sinuses: a case report and review of the literature. J Oral Maxillofac Surg, 70, 2347-51.

Kim JH, Lee SH, Park J, et al (2004). Extrapulmonary smallcell carcinoma: a single-institution experience. Jpn J Clin Oncol, 34, 250-4.

Lee SS, Lee JL, Ryu MH, et al (2007). Extrapulmonary small cell carcinoma: single center experience with 61 patients. Acta Oncol, 46, 846-51.

Lin IH, Hwang CF, Huang HY, Chien CY (2007). Small cell carcinoma of the nasopharynx. Acta Otolaryngol, 127, 206-8.

Lin YL, Chung CY, Chang CS, et al (2007). Prognostic factors in extrapulmonary small cell carcinomas. A large retrospective study. Oncology, 72, 181-7.

Naidoo J, Teo MY, Deady S, Comber H, Calvert P(2013). Should patients with extrapulmonary small-cell carcinoma receive prophylactic cranial irradiation? J Thorac Oncol, 8, 1215-21.

Nakahara S, Takemoto N, Inohara H (2012). Small cell carcinoma of the larynx treated by concurrent chemoradiotherapy: a case report. Case Rep Otolaryngol, 2012, 316165.

Ochsenreither S, Marnitz-Schultze S, Schneider A, et al (2009). Extrapulmonary small cell carcinoma (EPSCC): 10 years' multi-disciplinary experience at Charité. Anticancer Res, 29, 3411-5.

Segawa Y, Nakashima T, Shiratsuchi H, et al (2011). Small cell carcinoma of the tonsil treated with irinotecan and Cisplatin: a case report and literature review. Case Rep Oncol, 4, 587-91.

van der Laan TP, Plaat BE, van der Laan BF, Halmos GB (2015). Clinical recommendations on the treatment of neuroendocrine carcinoma of the larynx: A meta-analysis of 436 reported cases. Head Neck, 37, 707-15.

Wong YN, Jack RH, Mak V, Henrik M, Davies EA (2009). The epidemiology and survival of extrapulmonary small cell carcinoma in South East England, 1970-2004. BMC Cancer, 9, 209.

Yazici O, Ozdemir NY, Sendur MA, Aksoy S, Zengin N (2014). Current approaches for prophylactic cranial irradiation in extrapulmonary small cell carcinoma. Curr Med Res Opin, 30, 1327-36. 